\title{
Targeting transgene to seed resulted in high rate of morphological abnormalities of Camelina transformants
}

\author{
Dominika Šutá $^{1 \bowtie}$, Ildikó Matušíkováa $^{2}$ and Alžbeta Blehová ${ }^{1}$ \\ ${ }^{1}$ Department of Plant Physiology, Faculty of Natural Sciences, Comenius University in Bratislava, Ilkovičova 6, Mlynská \\ dolina, Bratislava 84215, Slovak Republic \\ ${ }^{2}$ Department of Ecochemistry and Radioecology, University of SS. Cyril and Methodius in Trnava, Nám. J. Herdu 2, \\ Trnava 91701, Slovak Republic
}

\section{Article info}

Article history:

Received: $18^{\text {th }}$ August 2019

Accepted: $10^{\text {th }}$ October 2019

\section{Keywords:}

Camelina sativa

Embryo developmental deformation

Floral dip transformation

Red fluorescent protein

\begin{abstract}
False flax (Camelina sativa L.) is currently under-exploited but highly promising oilseed crop. Combining Camelina's attractive agronomic traits with its unprecedented ease for genetic engineering makes it an ideal plant chassis for biotechnology applications, in particular synthetic biology strategies. For targeted expression of transgene particularly to seeds requires identification and application of seed specific promoters. In the present study two cultivars of Camelina, namely Zuzana and Smilowska, were used for transformation at early flowering stage using the floral dip method. The plants were inoculated with Agrobacterium bearing a construct for expression of red fluorescent protein (RFP) under the control of the seed specific cruciferin promoter CRUC from Arabidopsis. Transgenic seeds and plants were identified on the basis of red fluorescence (RFP) and kanamycin resistance. Relatively high transformation efficiency of $8 \%$ was achieved particularly for the cultivar Zuzana. However, many of regenerants exerted developmental deformations such as lack of shoot apical meristem, deformed or absent cotyledons, etc. Furthermore, the activity of the CRUC promoter was still active also in true leaves rendering this promoter as inappropriate for seed targeting of the transgene. Nevertheless, genetic transformation remains a tool for direct modulation of pathways for oil synthesis in oilseed crops.
\end{abstract}

\section{Introduction}

False flax, Camelina sativa (L.), is an ancient crop of the Brassicaceae cultivated in Europe as an important oilseed crop for many centuries before it was displaced by higher-yielding crops, such as canola, soybean or sunflower. Like other Brassicaceae, Camelina's seeds accumulate starch during the early stage of embryo development (Na et al. 2018), but later it largely diminishes when seeds mature. It is proposed that the turnover of starch during seed development is functionally linked with cell division (Andriotis et al. 2010). Camelina seeds store oil and protein as major carbon and nitrogen reserves (Gesch 2014).

The Camelina oil yields and fatty acid composition depends on cultivars, soil composition but also environmental conditions (Gesch 2014; Ševčík et al. 2018; Obeng et al. 2019). The proportion of polyunsaturated fatty acids (PUFAs) in seeds, for example, decreases with temperatures (Obour et al. 2017). Since higher content of unsaturated fatty acid in the oil is critical for its uses as jet fuel and biodiesel (Kim et al. 2015), the timing 
of Camelina planting to ensure flowering and seed filling, periods of adequate soil water supplyand favourable growing temperature are important for Camelina production. Further, Camelina oil is rich in omega-3 fatty acids but poor in minor lipid components such as tocopherols and phytosterols compared to the other conventional oilseeds (even most fish oils), rendering it suitable for food applications as health-promoting lipids (Budin et al. 1995; Belayneh et al. 2018).

Although Camelina has many attractive agronomic features (e.g. short lifecycle, remarkable adaptation to a wide range of climatic conditions, etc.), its relatively low oil yield (compared to other oilseed plants) represents a real limitation to it using in chemical and/or pharmaceutical industries (Faure and Tepfer 2015). Improving oil yield is therefore a priority for the development of this crop for large-scale use. Desired properties of the oil can be achieved by the use of various transformation techniques. Camelina can be successfully transformed using both the floral dip and floral vacuum infiltration methods (Lu and Kang 2008; Liu et al. 2012). Recently, two C. sativa cultivars were successfully transformed also with Agrobacterium tumefaciens, for which the shoot tips with apical meristems appeared the best target tissue (Sitther et al. 2018). Fully developed, intact transgenic Camelina plants can be obtained within 6 - 8 weeks ( $\mathrm{Lu}$ and Kang 2008; Sitther et al. 2018). Expression of transgenes can result in production of seed oil with attractive physicochemical properties such as reduced viscosity and freezing point, and thus suitable for preparation of biodegradable lubricants, emulsifiers, plasticizers, and second-generation biofuels (Liu et al. 2015; Bansal and Durrett 2016; Haslam et al. 2016). Recently Zhu et al. (2018) suggested that the maize master regulator, ZmLEC1, driven by a downstream seed-specific promoter, is a promising target for increasing oil yield in transgenic Camelina seeds. Further, Camelina plants transformed with EaDAcT gene from Euonymus alatus synthesize large amounts of sn-3-acetyl triacylglycerols (acetyl-TAGs), primarily in the endosperm and mature embryo cells (Durrett et al. 2010; Hu et al. 2017; Bansal et al. 2018; Chhikara et al. 2018). Modifying the composition of Camelina seed oil opens new possibilities for diversifying oilseed production, for example towards the accumulation of bioactive compounds (e.g. terpenes) used in food additives, cosmetics, drugs, and for other bio-based products. Transformation of Camelina per se does not appear as demanding, although failure of the applied method has also been reported ( $\mathrm{Lu}$ and Kang 2008). Moreover, targeted expression of transgene particularly to seeds can be problematic. Model organisms are being widely screened for identifying promoters that are tissueor developmental stage-specific to maximize the effect of transgene expression without affecting other tissues during growth and development (Jeong et al. 2014; Polóniová et al. 2015). The development of promoter systems expressed specifically in seeds or in particular constituents or tissues/compartments of seeds is indispensable not only for the mentioned reasons, but also to control the nourishment of the embryo, dispersal to a new location, and dormancy under unfavourable conditions (Jeong et al. 2014). Camelina has previously been transformed with seed-specific phaseolin promoter (Lu and Kang 2008).

In this work, we tested the suitability of the cruciferin (CRUC) promoter to drive transgene expression in Camelina seeds. This strong promoter from Arabidopsis thaliana is embryo-specific with activity that starts between mid-globular and early heart embryo stages (Becerra et al. 2006), but is inactive in other (vegetative) tissues like leaves or flowers (Mietkiewska et al. 2000). We show that the transformation of Camelina can be hampered, while potential reasons are discussed. We used two Camelina cultivars Zuzana and Smilowska, which are promising for breeding in Slovakia.

\section{Experimental}

\section{Bacteria}

The bacterial strain of Agrobacterium tumefaciens strain LBA4404 was used, carrying a binary vector pEV1 with the RFP reporter and selectable nptII genes (Moravčíková et al. 2008). The former gene was under the control of the cruciferin promoter sequence $(C R U C)$, while the latter one by the NOS promoter. Bacteria were cultivated on LB medium, (10 g. $\mathrm{L}^{-1}$ peptone, 6 g. $\mathrm{L}^{-1} \mathrm{NaCl}, 6$ g. $\mathrm{L}^{-1}$ yeast 

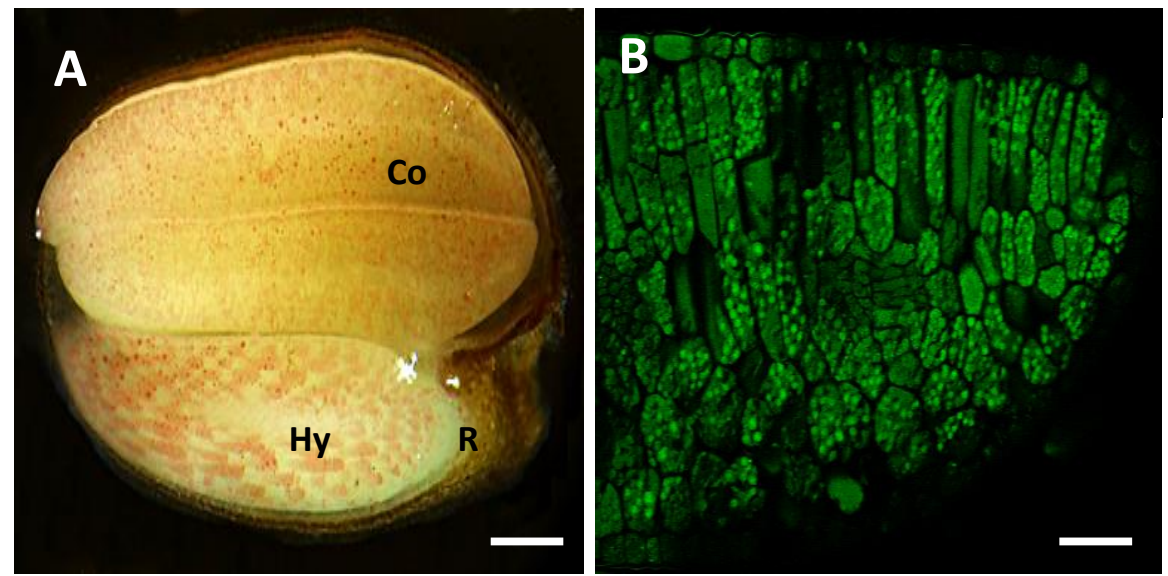

Fig. 1. Longitudinal sections of Camelina seeds observed by stereomicroscope (M 165 FC Leica, Germany) (A) and confocal laser microscopy fluorescence image (FV1200 IX83, Olympus, Japan) of cotyledons showing oil bodies stained with BODIPY TM 493/503 according to Martinčová et al. (2019) (B). Co -cotyledons; Hy hypocotyl; $\mathrm{R}-$ radicle. The bar represents $A=500 \mu \mathrm{m} ; \mathrm{B}=50 \mu \mathrm{m}$.

extract; pH 5.8). Bacterial suspension (300 $\mu \mathrm{L})$ and appropriate antibiotics (100 mg. $\mathrm{L}^{-1}$ of kanamycin and $25 \mathrm{mg} . \mathrm{L}^{-1}$ of rifampicin) were added into a liquid LB medium and cultivated for overnight on a shaker (SHAKER DOS-20L; $220 \mathrm{rpm})$ in the dark at $28{ }^{\circ} \mathrm{C}$. The Agrobacterium cells were separated from medium by centrifugation at $2,500 \mathrm{rpm}$ for $2 \mathrm{~min}$ and the pellet was suspended in the infiltration medium $\left(O D_{600} \sim 1.0\right)$, consisting of half-strength MS salts and $0.025 \%$ (v/v) Silwet L-77.

\section{Floral dip method of Camelina sativa transformation and selection}

Two C. sativa cultivars Zuzana (Czech Republic) and Smilowska (Poland) were transformed via floral dip infiltration using the above-mentioned strain of Agrobacterium tumefaciens.

One hundred $C$. sativa seeds planted in $15 \times 35 \mathrm{~cm}$ pot filled with soil were cultivated in a growth chamber under controlled environmental conditions $(16 / 8 \mathrm{~h}$ long-day photoperiod with the light intensity $100 \mu \mathrm{mol} . \mathrm{m}^{-2} \mathrm{~s}^{-1}$ and stable temperature $24{ }^{\circ} \mathrm{C}$ ). Plants at early flowering stage were dipped into Agrobacterium cell suspension for 15 seconds and covered with plastic dark film and placed in the dark for $24 \mathrm{~h}$. These $\mathrm{T}_{0}$ plants were then moved to the growth chamber and cultivated $(16 / 8 \mathrm{~h}$ long-day photoperiod; $100 \mu$ mol. $\mathrm{m}^{-2} \cdot \mathrm{s}^{-1}$ with stable temperature $24{ }^{\circ} \mathrm{C}$ ) until mature seeds were harvested.

One hundred seeds from $\mathrm{T}_{0}$ plants were sterilized with $4.7 \%(\mathrm{w} / \mathrm{v})$ sodium hypochlorite solution for $15 \mathrm{~min}$ and then washed three to five times with sterile distilled $\mathrm{H}_{2} \mathrm{O}$. Washed seeds were sown on Petri dishes with a half-strength MS medium (pH 5.8) supplemented with 10 g.L. $\mathrm{L}^{-1}$ sucrose, 7 g. $\mathrm{L}^{-1}$ agar and 150 mg.. $\mathrm{L}^{-1}$ kanamycin. The antibiotics concentration to be applied was determined based on preliminary screening of its (obviously negative) effect on non-transgenic germinating seedlings after 7 days growth. The seeds were cultivated in a growth chamber with a 16/8 h light/dark cycle for germination and seedling growth. Transgenic plants were examined for red fluorescence under a stereomicroscope M 165 FC (Leica, Germany) after 7 14 d cultivation.

\section{Results and Discussion}

Like other Brassicaceae plants, Camelina's seeds accumulate non-polar lipids, presence of which was detected in many oil bodies, primarily in cotyledons (Fig. 1). Oil content and properties render this species extremely attractive for food, but relatively cheaper agronomic costs and the possibility to modify the properties of its oil makes it promising for the biofuel industry as well.

Genetic transformation approach has been successful in achievement of the desirable Camelina traits (for review see Aznar-Moreno and Durrett 2017), while specific promoters are important for seed-targeted modification to occur. We transformed two Camelina cultivars Zuzana and Smilowska with Agrobacteria using floral dip method. Seeds were collected from 100 plants. A total of 100 seeds from each cultivar were let to germinate on media with kanamycin and the number of resistant individuals was scored. 
Table 1. Overview of the Camelina transformation.

\begin{tabular}{lllll}
\hline $\begin{array}{l}\text { Camelina } \\
\text { cultivar }\end{array}$ & \multicolumn{5}{c}{ Seeds of transformed plants } \\
& Total $^{\mathbf{a}}$ & RFP $^{\mathbf{b}}$ & Regenerants $^{\mathbf{c}}$ & TE [\%] \\
\hline Zuzana & 100 & 11 & 8 & 8 \\
Smilowska & 100 & 6 & 2 & 2 \\
\hline
\end{tabular}

a Total number of seeds from $\mathrm{T}_{0}$ plants screened;

${ }^{\mathrm{b}}$ Number of seeds expressing red fluorescence;

${ }^{\mathrm{c}}$ Number of potential transgenic regenerants identified on the basis of kanamycin resistance;

${ }^{\mathrm{d}}$ Transformation efficiency (TE) expressed as a number of kanamycin resistant regenerants obtained as percentage of the seeds used.

The data showed that two cultivars markedly differ in transformation efficiency; efficiency of $8 \%$ was achieved for the $c v$. Zuzana but only $2 \%$ for the $c v$. Smilowska (Table 1). The former value is much higher than the transformation efficiency of $0.8 \%$ obtained using the same transformation method by Liu et al. (2012), and also than the efficiency of $1.3 \%$ obtained using vacuum infiltration by $\mathrm{Lu}$ and Kang (2008). Noteworthy, the later authors failed to obtain transformed $C$. sativa ( $c v$. Celine) plants using floral dip technique. Previously,
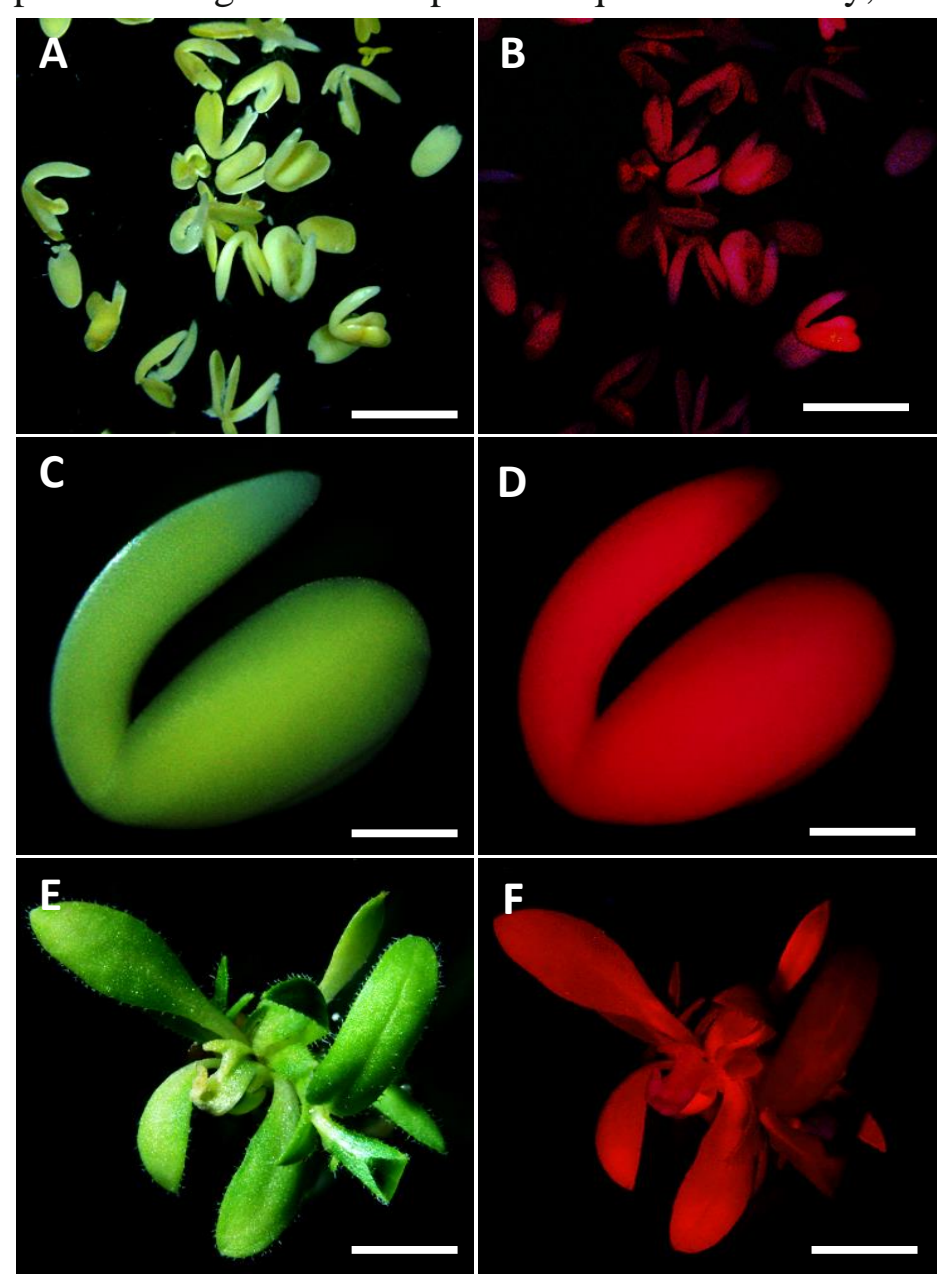

efficient transformation of two $C$. sativa cultivars (P1650159 and Pl650161) has been described by Sitther et al. (2018), while the authors concluded that shoot tips with apical meristems were the best target tissues for Agrobacteriummediated transformation of $C$. sativa plants in vitro. As easily scorable reporter gene we used the red fluorescing DsRFP, which has previously been used to transform Camelina under control of CaMV promoter (Lu and Kang 2008), and had shown to remain active in desiccated mature seeds with no obstruct excitation or emission of the fluorescence by the light-colored seed coat. We could not detect fluorescence in any intact Camelina seed at all, probably due to week transgene expression. In contrast, strong fluorescence was typical for germinating embryos (Fig. 2 and 3). However, not all red-fluorescing embryos survived on selection media in later developmental stage, pointing on insufficient tolerance to antibiotics (e.g. due to chimeric nature), or incomplete transgene (Boszorádová et al. 2019). The phenomenon of chimerism, for example, frequently occurs
Fig. 2. Selection of $\mathrm{RFP}^{+}$C. sativa embryos after 7 days of cultivation $(\mathbf{A}-\mathbf{D})$ and regeneration of $\mathrm{RFP}^{+}$ potential transgenic plants $(\mathbf{E}-\mathbf{F})$ after 14 days of cultivation. The bar represents $\mathbf{A}, \mathbf{B}=1 \mathrm{~cm}$; $\mathbf{C}, \mathbf{D}=250 \mu \mathrm{m} ; \mathbf{E}, \mathbf{F}=1 \mathrm{~cm}$. 



Fig. 3. Generation of transgenic Camelina sativa plants. Seeds of transformed plants were plated on media with $150 \mathrm{mg} . \mathrm{L}^{-1}$ kanamycin (A, D) and their transgenic nature was identified on the basis of red fluorescence $\left(\mathrm{RFP}^{+}\right)$and resistance to antibiotics. Non-transgenic Camelina seedlings (B) had white cotyledons and showed very low or no RFP activity (C). Red fluorescence indicated transgene expression in transgenic Camelina plants regenerated on MS media with kanamycin (F). The bars at $\mathbf{A}-\mathbf{F}$ $=1 \mathrm{~cm}$.

to a different extent in all systems where a recombination event has to take place in multicellular structures, e.g. during development from calli (Moravčíková et al. 2008).

Surprisingly, red fluorescence of surviving transformants was observed also later during development and growth, especially in the regenerants of the ana (Fig. 2 and 3). This suggests that the CRUC promoter does not stop activation of the $r f p$ as expected. Ectopic expression of this promoter has been reported previously in rapeseed (Boszorádová et al. 2019) and tobacco (Moravčíková et al. 2008), but shifted activation of a heterologous promoter in time has also been observed by others (Luo et al. 2007; Polóniová et al. 2015). Given the critical requirement of transgene expression solely in the seeds of Camelina, the CRUC appears inappropriate for use in oil biotechnology.

The transgenic (in each case still RFP positive) seedlings have green expanded cotyledons and green true leaves. In contrast, control and nontransgenic seedlings had white cotyledons and they were unable to produce true leaves in the given (cultivation) conditions (Fig. 3). The surprising result of our transformation efforts was $~ 30 \%$ of aberrant phenotypes seedlings (Fig. 3 and 4).

The observed phenotypic and developmental abnormalities included reduced or partially disrupted shoot apical meristems, and deformed or absent cotyledons (Fig. 4). These defects likely hamper the completion of embryo development and/or seed germination. According to Schwartz et al. (1994), defects in Arabidopsis embryo development appear in the globular stage of embryogenesis, while the abnormalities in the suspensor function were detected soon after at the heart stage. Altered development of the embryo in mutant seeds leads indirectly to the proliferation of suspensor cells and expression of properties characteristic of the embryo proper. In this context is also important that storage protein and lipid bodies, which normally accumulate only in the Arabidopsis embryo, were present in both structures (Schwartz et al. 1994). This is consistent with the work recently published by Zhu et al. (2018), who achieved more than $20 \%$ increased oil content in the transgenic Camelina seeds, but they did not observe any adverse effects on growth and development. Furthermore, the changes in the composition of oil do not affect the germination of Camelina seeds, and therefore these oils can be used by plants as an energy source during the embryo development, seed germination, in regulation processes of seedlings growth and development, and even during the cultivation in the field (Liu et al. 2015).

Previously, tissue-specific expression of aspartate aminotransferase in Brassica napus produced transformants with aberrant phenotype, such as abnormal leaf morphology and photosynthesis as well as stunted growth (Wu et al. 2002; Shu et al. 2002; Ahlert et al. 2003; McAllister et al. 2016). Ahlert et al. (2003) speculated that the position of transgene insertion may have played a key role in the phenomenon. 


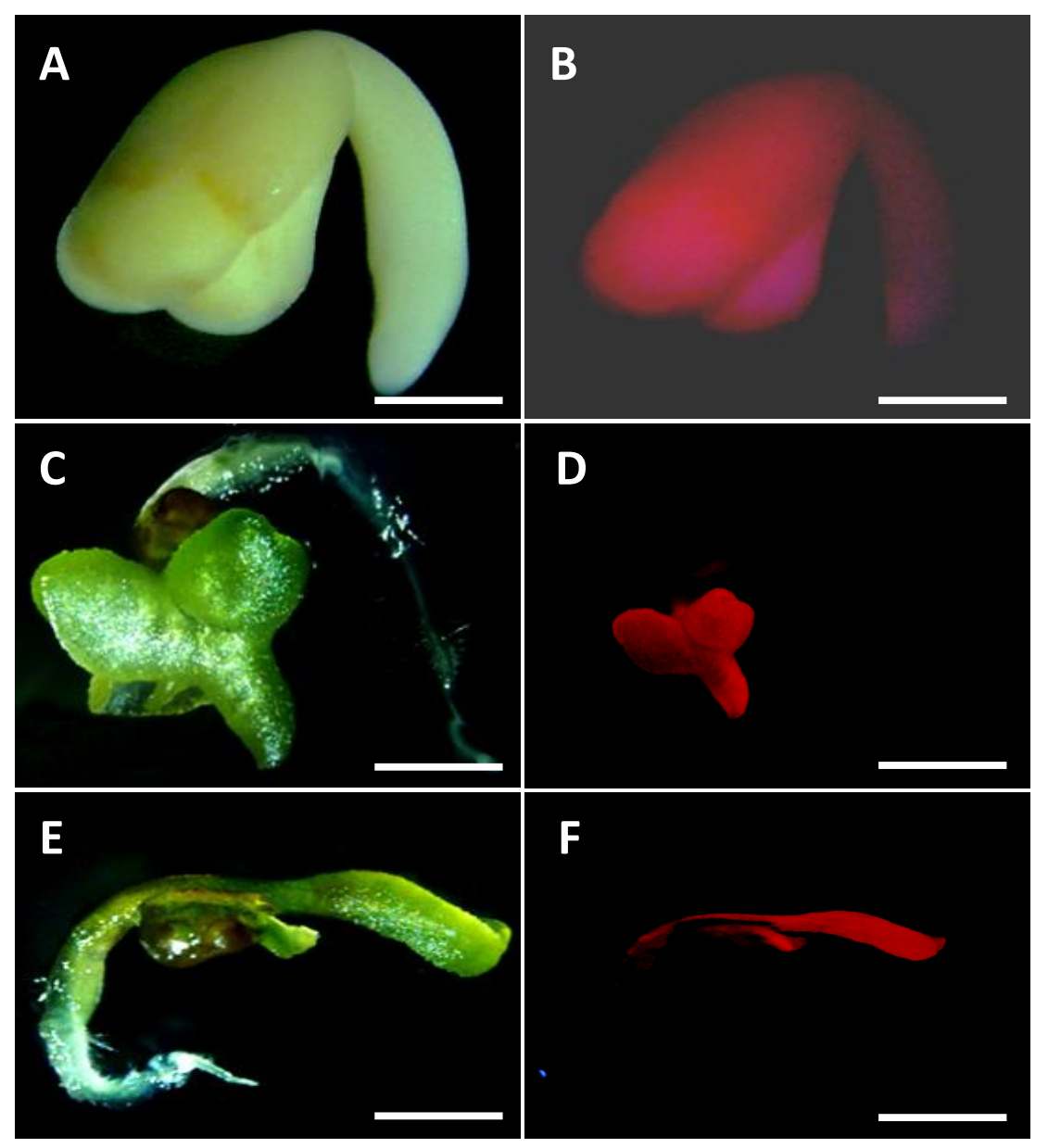

Fig. 4. Red fluorescence in large number of embryos with developmental deformations in development, such as deformed $(\mathbf{A}-\mathbf{D})$ or absent cotyledons $(\mathbf{E}-\mathbf{F})$. The bar represents $\mathbf{A}, \mathbf{B}=250 \mu \mathrm{m} ; \mathbf{C}-\mathbf{F}=1 \mathrm{~cm}$.

Since aberrant transformants are undesired sideproducts of many experiments, they are rarely discussed in detail and their reasons are not further explored. There are many quite well described reasons for changes at DNA level (ranging from point mutations and methylation differences to transposon induction, gene amplification, chromosomal aberrations and ploidy level changes; Kaeppler et al. 2000; Jain 2001; Bregitzer et al. 2002; Boszorádová et al. 2011, 2014). Numerous aspects of plant transformation are associated with the stress of the exposed tissues. For example, the use of antibiotics - especially at higher concentrations like in our study - may induce epigenetic and/or genetic changes of the plant genome (Bardini et al. 2003; Madlung and Comai 2004). The Agrobacterium infection itself, and also insertions of small fragments of transgenic DNA can also be a potential source of genome-wide mutations. As these would usually be missed by Southern blot and even by polymorphism analysis techniques, the numbers of genome-wide mutations in plants transformed by Agrobacterium (and possibly also by particle bombardment) are probably underestimated (Makarevitch et al. 2003). Importantly, the presence of strong transgene promoters, including the commonly used cauliflower mosaic virus $(C a M V)$ promoter and also the $C R U C$ promoter used in this study, may also result in mis-expression (especially overexpression) of endogenous genes (Moravčíková et al. 2008; Boszorádová et al. 2019) at a distance of up to $12 \mathrm{kbp}$ (Ichikawa et al. 2003). Transcriptional read-through and improper mRNA processing (protein translation/folding) can also occur when the NOS terminator is used (Rang et al. 2005).

\section{Conclusions}

Since the current plant transformation methods are mutagenic, efficient production of safe transgenic plants for biotechnology would require more data on the frequency and molecular basis of 
transformation-induced mutations (Wilson et al. 2006). Those presently available describe aberrant Arabidopsis plants created by Agrobacteriummediated transformation, while those from other species (including important crop plants) describe at most a few transgenic individuals with incompletely analysed genome changes. In our system, both strong (ectopically active) promoter and terminator combined with high antibiotics concentrations could be responsible for aberrant regenerants. Though formation of aberrant plants has not been reported as consequence of neither RFP production not CRUC promoter activity, for Camelina the $C R U C$ did not prove to be promising for seed-directed genome modification.

\section{Acknowledgement}

This work was supported by the Slovak Research and Development Agency under the contract No. APVV-160051. We sincerely thank to Mgr. Peter Kaštier PhD. for his excellent technical assistance.

\section{Conflict of Interest}

The authors declare that they have no conflict of interest.

\section{References}

Ahlert D, Ruf S, Bock R (2003) Plastid protein synthesis is required for plant development in tobacco. Proc. Natl. Acad. Sci. 100: 15730-15735.

Andriotis VME, Pike MJ, Kular B, Rawsthorne S, Smith AM (2010) Starch turnover in developing oilseed embryos. New Phytol. 187: 791-804.

Aznar-Moreno JA, Durrett, TP (2017) Review: Metabolic engineering of unusual lipids in the synthetic biology area. Plant Sci. 263: 126-131.

Bansal S, Durrett TP (2016) Camelina sativa: An ideal platform for the metabolic engineering and field production of industrial lipids. Biochimie. 120: 9-16.

Bansal S, Kim HJ, Na G, Hamilton ME, Cahoon EB, Lu C, Durrett TP (2018) Towards the synthetic design of camelina oil enriched in tailored acetyl-triacylglycerols with medium-chain fatty acids. J. Exp. Bot. 69: 43954402.

Bardini M, Labra M, Winfield M, Sala F (2003) Antibioticinduced DNA methylation changes in calluses of Arabidopsis thaliana. Plant Cell Tiss. Org. Cult. 72: 157-162.

Becerra C, Puigdomenech P, Vicient CM (2006) Computational and experimental analysis identifies Arabidopsis genes specifically expressed during early seed development. BMC Genomics. 7: 38.
Belayneh HD, Wehling RL, Zhang Y, Ciftci ON (2018) Development of omega-3-rich Camelina sativa seed oil emulsions. Food Sci. Nutr. 6: 440-449.

Boszorádová E, Matušíková I, Libantová J, Zimová M, Moravčíková J (2019) Cre-mediated marker gene removal for production of biosafe commercial oilseed rape. Acta Physiol. Plant. 41: 73.

Boszorádová E, Libantová J, Matušíková I, Moravčíková J (2014) Application of Arabidopsis tissue-specific CRUC promoter in the Cre/loxP self-excision strategy for generation of marker-free oilseed rape: potential advantages and drawbacks. Acta Physiol. Plant. 36: 13991409.

Boszorádová E, Libantova J, Matusikova I, Poloniova Z, Jopcik M, Berenyi M, Moravcikova J (2011) Agrobacterium-mediated genetic transformation of economically important oilseed rape cultivars. Plant Cell Tiss. Org. Cult. 107: 317-323.

Bregitzer P, Zhang S, Cho MJ, Lemaux PG (2002) Reduced somaclonal variation in barley is associated with culturing highly differentiated, meristematic tissue. Crop Sci. 42: 1303-1308.

Budin JT, Breene WM, Putnam DH (1995). Some compositional properties of camelina (Camelina sativa L. Crantz) seeds and oils. J. Am. Oil Chem. Soc. 72: 309-315

Chhikara S, Abdullah HM, Akbari P, Schnell D, Dhankher OP (2018) Engineering Camelina sativa (L.) Crantz for enhanced oil and seed yields by combining diacylglycerol acyltransferase1 and glycerol-3phosphate dehydrogenase expression. Plant Biotechnol. J. 16: 1034-1045.

Durrett TP, McClosky DD, Tumaney AW, Elzinga DA, Ohlrogge J, Pollard M (2010) A distinct DGAT with $s n-3$ acetyltransferase activity that synthesizes unusual, reduced-viscosity oils in Euonymus and transgenic seeds. Proc. Natl. Acad. Sci. 107: 9464-9469.

Faure JD, Tepfer M (2015) Camelina, a swiss knife for plant lipid biotechnology. OCL. 23: D503.

Gesch RW (2014) Influence of genotype and sowing date on camelina growth and yield in the north central US. Ind. Crops Prod. 54: 209-215.

Haslam RP, Sayanova O, Kim HJ, Cahoon EB, Napier JA (2016) Synthetic redesign of plant lipid metabolism. Plant J. 87: 76-86.

Hu Z, Wu Q, Dalal J, Vasani N, Lopez HO, Sederoff HW, Qu R (2017) Accumulation of medium-chain, saturated fatty acyl moieties in seed oils of transgenic Camelina sativa. PLoS One 12: e0172296.

Ichikawa T, Nakazawa M, Muto S, Gohda K, Suzuki K, Ishikawa A, Kobayashi H, Yoshizumi T, Tsumoto Y, Tsuhara Y, Lizumi H, Goto Y, Matsui M (2003) Sequence database of 1172 T-DNA insertion sites in Arabidopsis activation-tagging lines that showed phenotypes in $\mathrm{T} 1$ generation. Plant J. 36: 421-429.

Jain SM (2001) Tissue culture-derived variation in crop improvement. Euphytica. 118: 153-166.

Jeong HJ, Choi JY, Shin H, Bae JM, Shin JS (2014) Seedspecific expression of seven Arabidopsis promoters. Gene. 553: $17-23$. 
Kaeppler SM, Kaeppler HF, Rhee Y (2000) Epigenetic aspects of somaclonal variation in plants. Plant Mol. Biol. 43: $179-188$.

Kim HJ, Silva JE, Vu HS, Mockaitis K, Nam JW, Cahoon EB (2015) Toward production of jet fuel functionality in oilseeds: identification of FatB acyl-acyl carrier protein thioesterases and evaluation of combinatorial expression strategies in Camelina seeds. J. Exp. Bot. 66: 4251-4265.

Liu J, Rice A., McGlew K, Shaw V, Park H, Clemente T, Pollard M, Ohlrogge J, Durrett TP (2015) Metabolic engineering of oilseed crops to produce high levels of novel acetyl glyceride oils with reduced viscosity, freezing point and calorific value. Plant Biotechnol. J. 13: 858-865.

Liu X, Brost J, Hutcheon C, Guilfoil R, Wilson AK, Leung S, Shewmaker ChK, Rooke S, Nguyen T, Kiser J, De Rocher J (2012) Transformation of the oilseed crop Camelina sativa by Agrobacterium-mediated floral dip and simple large-scale screening of transformants. In Vitro Cell. Dev. Biol. Plant. 48: 462-468.

Luo KM, Duan H, Zhao DG, Zheng XL, Deng W, Chen YQ, Stewart CN, McAvoy R, Jiang XN, Wu YH, He AG, Pei Y, Li Y (2007) 'GM-gene-deletor': fused loxP-FRT recognition sequences dramatically improve the efficiency of FLP or CRE recombinase on transgene excision from pollen and seed of tobacco plants. Plant Biotechnol. J. 5: 263-274.

Lu Ch, Kang EJ (2008) Generation of transgenic plants of a potential oilseed crop Camelina sativa by Agrobacterium-mediated transformation. Plant Cell Rep. 27: 273-278.

Madlung A, Comai L (2004) The effect of stress on genome regulation and structure. Ann. Bot. 94: 481-495.

Makarevitch I, Svitashev SK, Somers DA (2003) Complete sequence analysis of transgene loci from plants transformed via microprojectile bombardment. Plant Mol. Biol. 52: 421-432.

Martinčová M, Kaštier P, Krasylenko YA, Gajdoš P, Čertík M, Matušíková I, Blehová A (2019) Species-specific differences in architecture and chemical composition of dodder seeds. Flora 256: 61-68.

Mc Allister ChH, Wolansky M, Good AG (2016) The impact on nitrogen-efficient phenotypes when aspartate aminotransferase is expressed tissue-specifically in Brassica napus. New Negat. Plant Sci. 3-4: 1-9.

Mietkiewska E, Dees D, Nap JP (2000) Seed specific GUS geneexpression directed by the Arabidopsis cruciferin $\mathrm{C}$ promoter in tobacco and Arabidopsis. In Session Plant Lipid Metabolisms, $6^{\text {th }}$ International Congress of Plant Molecular Biology, ISPMB, June 18 - 24, Quebec, Canada, p. 20-24.

Moravčíková J, Vaculková E, Bauer M, Libantová J (2008) Feasibility of the seed specific cruciferin $\mathrm{C}$ promoter in the self-excision Cre/loxP strategy focused on generation of marker-free transgenic plants. Theor. Appl. Genet. 117:1325-1334.

Na GN, Aryal N, Fatihi A, Kang J, Lu Ch (2018) Seedspecific suppression of ADP-glucose pyrophosphorylase in Camelina sativa increases seed size and weight. Biotechnol. Biofuels 11: 330.

Obeng E, Obour AK, Nelson, NO, Aznar-Moreno JA, Ignacio A, Ciampitti IA, Donghai WD, Durrett TP (2019) Seed yield and oil quality as affected by Camelina cultivar and planting date. J. Crop Improv. 33: 202-222.

Obour AK, Obeng E, Mohammed YA, Ciampitti IA, Durrett TP, Aznar-Moreno, JA, Chen, Ch (2017) Camelina seed yield and fatty acids as influenced by genotype and environment. Agron. J. 109: 947-956.

Polóniová Z, Jopčík M, Matušíkova I, Libantová J, Moravčíková J (2015) The pollen- and embryospecific Arabidopsis DLL promoter bears good potential for application in marker-free Cre/loxP self-excision strategy. Plant Cell Rep. 34: 469-481.

Rang A, Linke B, Jansen B (2005) Detection of RNA variants transcribed from the transgene in Roundup Ready soybean. Eur. Food Res. Technol. 220: 438-443.

Schwartz BW, Yeung EC, Meinke DW (1994) Disruption of morphogenesis and transformation of the suspensor in abnormal suspensor mutants of Arabidopsis. Development 120: 3235-3245.

Shu Q, Cui H, Ye G, Wu D, Xia Y, Gao M, Altosaar I (2002) Agronomic and morphological characterization of Agrobacterium-transformed Bt rice plants. Euphytica. 127: 345-352.

Sitther V, Tabatabai B, Enitan B, Dhekney S (2018) Agrobacterium-mediated transformation of Camelina sativa for production of transgenic plants. J. Biol. Methods. 5: e83.

Ševčík P, Joríková L, Hozlár P, Hájeková E, Ondrejíčková P (2018) The effect of growing conditions on Camelina (Camelina sativa L.) oil content - sustainable feedstock for biofuels production. In $6^{\text {th }}$ International Conference on Chemical Technology. 16.-18.4. 2018 Mikulov, Czech Republic, p. 244-247.

Wilson AK, Latham JR, Steinbrecher RA (2006) Transformation-induced mutations in transgenic plants: Analysis and biosafety implications. Biotechnol. Genet. Eng. 23: 209-238.

Wu DX, Shu QY, Wang ZH, Cui HR, Xia YW (2002) Quality variations in transgenic rice with a synthetic crylAb gene from Bacillus thuringiensis. Plant Breed. 121: 198-202.

Zhu Y, Xie L, Chen GQ, Lee MY, Loque D, Scheller HV (2018) A transgene design for enhancing oil content in Arabidopsis and Camelina seeds. Biotechnol. Biofuels. 11: 46. 